\section{THE SENIOR}

\section{CARDIOVASCULAR SURGICAL} SOCIETY

\section{To the Editor:}

Recently, a prominent cardiovascular surgeon visited my private office and was reviewing the items on my "ego wall," which features diplomas, certificates, and a few photographs. $\mathrm{He}$ asked me about a prominent plaque entitled "Senior Cardiovascular Surgical Society" (Figure 1). I explained that in 1991, Drs George Magovern, Sr, and John Ochsner had created a society of senior cardiovascular surgeons, all of whom were past 60 years old and were respected pioneers in the field. They included Jay Ankeney, Case Western Reserve University Medical Center; Harvey Bender, Vanderbilt University Medical Center; Mortimer Buckley, Massachusetts General Hospital; Richard Cleveland, Tufts University Medical Center; John Connolly, University of California Irvine Medical Center; Denton Cooley, Texas Heart Institute; James DeWeese, University of Rochester Medical Center; Paul Ebert, University of California San Francisco Medical Center (and at the time Executive Director, American College of Surgeons); James Mackenzie, University of Medicine and Dentistry, NJ; George Magovern, Sr, Allegheny General Hospital; John Ochsner, Ochsner Clinic Foundation; and Norman Shumway, Stanford University Medical Center. Most of us

\footnotetext{
The Editor welcomes submissions for possible publication in the Letters to the Editor section that consist of commentary on an article published in the Journal or other relevant issues. Authors should: - Include no more than 500 words of text, three authors, and five references. - Type with double-spacing - See http://jtcs.ctsnetjournals.org/misc/ifora.shtml for detailed submission instructions. - Submit the letter electronically via jtcvs.editorialmanager.com. Letters commenting on an article published in the JTCVS will be considered if they are received within 6 weeks of the time the article was published. Authors of the article being commented on will be given an opportunity of offer a timely response ( 2 weeks) to the letter. Authors of letters will be notified that the letter has been received. Unpublished letters cannot be returned.
}

were chairs of our departments of surgery. Most importantly, we all shared one main interest - the game of golf. I designed the society's diploma, which included a $\operatorname{logo}$ and a Latin motto, Mors Ortiosa Est, roughly translated as "Death Takes a Holiday." (We joked that the mortality was expected to decline during our absence from our respective institutions.)

The initial group consisted of 12 members, so there were 3 foursomes. Each annual meeting was held at a resort area with a well-known attached golf course. The inaugural gettogether was held in 1992, at the PGA National Resort, Palm Beach Gardens, Fla. All the meetings included a series of scientific sessions, which covered a wide array of cardiovascular topics and satisfied the Internal Revenue Service's requirements for deductions. At many meetings, a scientific presentation was made by an invited guest, who was often a good golfer and played with our group. We enjoyed the presentations, the sport, the informality, and the fellowship. In 2001, at The Villas of Grand Cypress, in Orlando, Fla, I made my one and only hole-in-one on a 165-yard hole. Cocktails that evening were on me!

A few years ago, the meetings were discontinued. The last one was held in
2003 at Torrey Pines, in San Diego. Norman Shumway declined to attend because of deep venous thrombosis. Soon, similar ailments began to occur among the members. With time, most of us retired from surgery and cut back on playing golf for health reasons. Some have gone to the Great Operating Room in the Sky. I miss our meetings, which are among my fondest recollections. It seems a pity that our specialty no longer has a group of senior surgeons dedicated to education, fellowship, and recreation-especially golf. I would encourage eligible surgeons in our organization to develop a new chapter of the Senior Cardiovascular Surgical Society.

Denton A. Cooley, MD Surgeon-in-Chief and President Emeritus

Texas Heart Institute at St. Luke's Episcopal Hospital Houston, Tex

This Letter to the Editor is being co-published in The Journal of Thoracic and Cardiovascular Surgery and The Annals of Thoracic Surgery.

Copyright (c) 2013 by The American Association for Thoracic Surgery and The Society of Thoracic Surgeons

http://dx.doi.org/10.1016/ j.jtcvs.2013.02.062

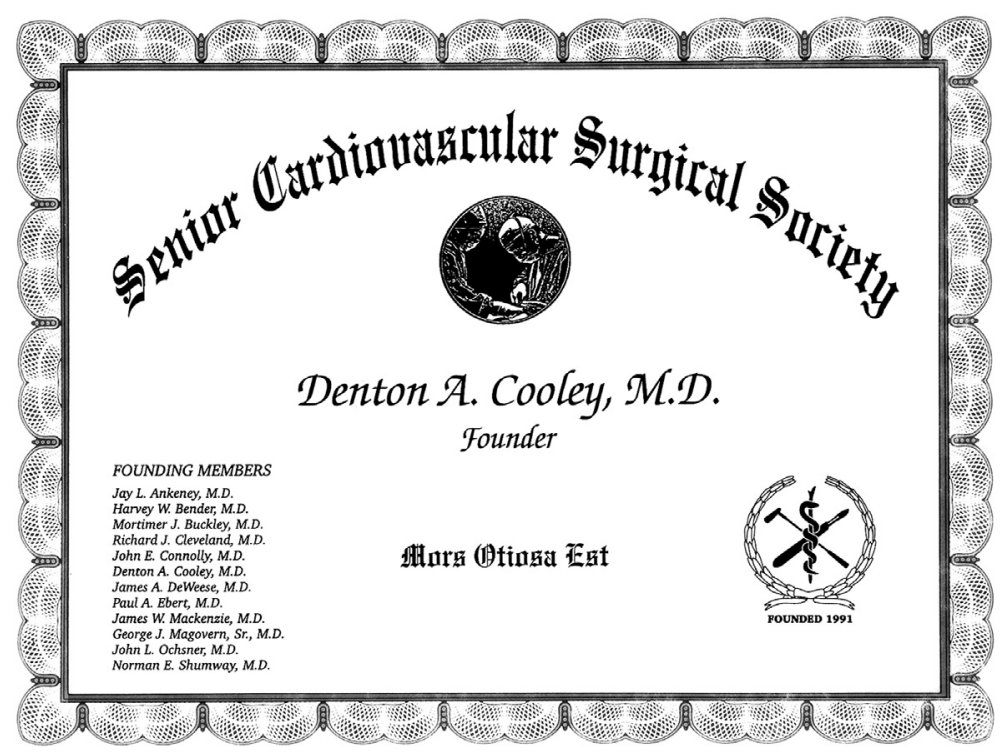

FIGURE 1. Senior Cardiovascular Surgical Society "diploma” from the wall of Dr Denton Cooley. 